ISSN: 1984-6266

\section{The Influence of Law 12.431 of 2011 on Encouraged Debenture Spread}

\author{
Rodolfo Vieira Nunes \\ USP - Universidade de São Paulo \\ rodolfonunes@usp.br \\ Agostinho Moura dos Santos \\ UnB - Universidade de Brasília \\ agostinhoms@gmail.com

\section{George André Willrich Sales} \\ Faculdade FIPECAFI
}

\section{Resumo}

A aplicação de recursos na infraestrutura é de vital importância para a expansão da infraestrutura nacional. O governo promulgou a Lei n 12.431 / 2011, que prevê a isenção do imposto de renda para pessoas físicas residentes no Brasil ou estrangeiros que investirem em debêntures relacionadas à implantação de projetos de infraestrutura (debêntures incentivadas). Assim, espera-se que o benefício fiscal, concedido pela Lei, seja um dos fatores determinantes na precificação das debêntures, uma vez que, pela teoria da escolha racional, busca-se testar a hipótese de que o spread exigido para as debêntures incentivadas é equivalente ao spread de qualquer outra debênture do mesmo nível de risco ajustado pelo impacto fiscal do imposto de renda. No entanto, os resultados não mostram que 0 spread das debêntures incentivadas é inferior ao spread das debêntures não incentivadas. A contribuição da pesquisa aborda questões sobre as políticas públicas setoriais de governo e as características do mercado de debêntures no Brasil, a pesquisa mostrou uma nova perspectiva sobre este mercado de investimento nos últimos anos.

Palavras-chave: Lei 12.431. Infraestrutura. Debêntures. Spread.
Recebimento:

28/10/2020

Aprovação:

19/03/2021

Editor responsável pela aprovação do artigo:

Dra. Luciana Klein

Editor responsável pela edição do artigo:

Dra. Luciana Klein

Avaliado pelo sistema:

Double Blind Review

A reprodução dos artigos, total ou parcial, pode ser feita desde que citada a fonte.

PROGRAMA DE PÓS-GRADUAÇ̃̃O EM CONTABILIDADE

MESTRADO E DOUTORADO

DOI:

http://dx.doi.org/10.5380/rcc.v13i1.77569 


\title{
THE INFLUENCE OF LAW 12.431 OF 2011 ON ENCOURAGED DEBENTURE SPREAD
}

\begin{abstract}
Applying resources in the infrastructure is vitally important for the expansion of national infrastructure. The government enacted Law No. 12.431/2011, which provides for income tax exemption for individuals residing in Brazil or foreigners who invest in debentures related to the infrastructure projects implementation (encouraged debentures). Thus, it is expected that the tax benefit, granted by the Law, will be one of the determining factors in the pricing of debentures, since, by the rational choice theory, it seeks to test the hypothesis that the spread required for encouraged debentures is equivalent to the spread of any other debenture of the same level of risk adjusted for the income tax fiscal impact. However, the results do not show that the spread of encouraged debentures is lower than the spread of non-encouraged debentures. The research contribution addresses questions about government sectorial public policies and the characteristics of the debentures market in Brazil, the research showed a new outlook on this investment market in recent years.
\end{abstract}

Keywords: Law 12.431; Infrastructure; Debenture; Spread.

\section{Introduction}

Investment in national infrastructure is of paramount importance to national development in that it seeks to mitigate deficiencies in strategic sectors such as energy, communications, sanitation, transport, etc. Originally, the Brazilian State operated as the main executor of infrastructure projects. This model has been changed to allow the participation of third parties in the construction, improvement, and operation of important public facilities, through several different legal instruments, among them the concession.

According to Di Pietro (2017), partnerships with private entities for the performance of relevant social activities seek to achieve three main objectives: a) reduction of the state apparatus (delegation of public services and termination of administrative bodies and entities); b) fostering private initiative in the performance of activities of public interest; and c) efficiency, through the introduction of administrative management in order to flexibilize procedures and look for the results.

For Oliveira (2015), the need for efficient administrative management led the State to develop several public services through concessions to the private sector (concessionaires), and regulation, in general, was in charge of regulatory agencies. In a way, this portrays that Brazil has been experiencing a stage characterized by a huge demand for investments in infrastructure and public services, before dramatically restrictive budgets.

The financing model carried out mostly by the public sector, mainly through the National Bank for Economic and Social Development - BNDES, has been showing signs of exhaustion, mainly due to the severe economic crisis that Brazil has experienced, which resulted in the shortage of funds from the Federal Treasury to meet the financing demanded for infrastructure investments in the country.

Assaf Neto (2014) points out that most of the financing of Brazilian companies stems from the bank credit and that the funding of productive investments in Brazil have trouble in meeting the actual financing needs of companies. For the author, the longer-term operations are offered in Brazil by official financial institutions such as the BNDES system.

In this scenario, in which the private partners receive incentives to seek other forms of financing that align to the profile of the investments to be made, the issue of debentures may become an interesting source of funding for infrastructure projects. 
Nunes (2014) understands that the main advantage of issuing debentures is flexibility, as the maturity of each series, the guarantees, the interest payment flow, and the amortization can be tailored to meet each project needs. The author also mentions the reduction of funding costs as an advantage of this type of instrument.

The Brazilian government sought to boost private fundraising for domestic infrastructure funding through Law No. 12.431, which established, among other things:

i. Zero rate for income tax incident on long-term private securities yields, issued by nonfinancial companies, when paid, when credited, when delivered or remitted to a beneficiary resident or domiciled abroad (art. 1); and

ii. Zero rate for income tax on long-term debentures income issued to finance infrastructure projects when earned by individuals (art. 2).

The explanatory memorandum to the aforementioned legal provision argues that the measures are necessary to enable the construction of a private long-term financing market. It also stressed need to acknowledge that the validation of the good economic growth prospects at that time demanded the construction of a new funding base for projects of greater maturity, which implies greater participation of private sector as an additional source of funding.

The initiative, however, is not new. Decree-Law no. 157, of February 10, 1967, had already dealt with the granting of tax incentives for the companies' capitalization and the granting of incentives for the purchase of shares and debentures. The mechanism allowed income taxpayers to allocate up to $10 \%$ of the due income tax each year to funds from financial institutions. These financial institutions should invest the aforementioned funds in the purchase of shares and debentures issued by companies covered by the Decree.

For Moll (2010) the Rational Choice Theory is a normative theory that proposes an explanation for intentional human actions. According to this rationale, agents seek to optimize their actions through a process that involves the analysis of all costs and benefits related to each alternative, seeking to maximize the utility of the results to be achieved with the aforementioned decision.

In line with this theory, this research assumes the economic rationality of agents in the sense that for the same level of risk, the rational investor will choose the investment alternative that presents the greatest expected return (Assaf Neto, 2014). That is, given the same level of risk, the alternative that maximizes the investor's utility is the one with the highest expected return, as recommended by the Rational Choice Theory.

In another round, the corporate finance literature indicates that the interest rate on a debt security is composed of a base interest rate and a spread that compensates for the various specific risks of each security. The spread is understood as the difference between a specific rate and a reference rate. According to Sheng and Saito (2005), the main reference indicators used by the market are the IGP-M (General Market Price Index), the DI (Interbank Deposits), the National Association of Investment Banks (ANBID) and the Long-Term Interest Rate (LTIR).

The encouraged debenture, or infrastructure debenture, was a regulated financial instrument with the implementation of Law No. 12,431 / 2011. According to some studies (Almeida \& Bazilio, 2015; Bragança, Pessoa \& Souza, 2015; Wajnberg, 2015), the main advantage of this type of debenture is the tax exemption given to individual or foreign investors, representing an effective benefit of, at least, $15 \%$ on the remuneration of the security $(15 \%$ is the minimum tax rate on capital gains paid by debenture holders in non-incentive debentures). As for Brazilian corporations, there is no total exemption, but there is a reduced rate of income tax of $15 \%$ for companies taxed by the real profit (in a non-incentive debenture, the rate for companies can reach $34 \%$ ). This type of debenture can only be issued for investment projects considered as a priority (infrastructure).

In view of the above, the core of this research is guided by the question: did the enactment of Law No. 12,431 , of June 24,2011 , positively influence the debentures spreads issued after the regulation? 
Based on the new law, one can test the effectiveness of the public policy for granting tax benefits for the issuance of incentive debentures by questioning whether, in fact, the cost of financing through incentivized debentures (translated by the spread in relation to public security) is lower than the cost of raising funds through non-incentive debentures. Therefore, as a research hypothesis expect the spread of encouraged debentures will be less than no-encouraged.

For the Brazilian market, government securities are commonly used as parameters for risk-free investments. Therefore, the spread of any security represents the excess remuneration rate of that security compared to the public security with similar features (index and term). Hence, it was sought to analyze the spread of infrastructure debentures and compare it with the spread of debentures that do not have the benefit of Law no. 12,431 / 2011.

Thus, this paper investigated whether the incentivized debentures provided cheaper financing for investment projects, in order to reflect on their spread compared to non-incentivized debentures.

According to the literature, research on liquidity of corporate bonds in Brazil is still little explored when compared with research on liquidity in the stock market. Studies in consolidated markets based on liquidity risk are usually directed to research the dynamics of markets, such as understanding how the liquidity premium is allocated in the spreads of assets and how it is priced, so that it is possible to look for ways to decrease it (Gonçalves \& Sheng, 2010).

However, the increase in demand from institutional investors for corporate bonds in recent years has meant that the study of the pricing dynamics of these securities has increased significantly. The differential presented by this article is to make a comparison between the spreads of the incentive debentures and of the non-incentive debentures, since the studies usually relate the two forms of debentures separately. The use of this approach in the comparison of spreads is supported by some studies (Houweling, Mentink \& Vorst, 2005; Fraletti \& Eid Junior, 2005; Gonçalves \& Sheng, 2010; Giacomoni \& Sheng, 2013), which demonstrate the importance and the need to know the spread value of each security and which variables can influence it.

The other reason for undertaking this study is to identify the influence of state regulation on the interest rate formation of financing instruments used for funding infrastructure projects in the country. It is not difficult to argue that government action aims to boost infrastructure development in Brazil, as a way to enhance national economic development.

The rationale advocated by the federal government for proposing the tax benefit to infrastructure debentures presupposes that these instruments enable a lower cost of fundraising for projects that seek to foster national infrastructure.

One cannot forget that this governmental measure ultimately results in a waiver of revenue by the federal government. Thus, one can point out the effectiveness of the initiative insofar as it is verified that, in fact, infrastructure projects are able to raise funds at a lower cost. In this line, this research contributes to the assessment of the tax exemption granted to the debentures aimed at infrastructure projects.

\section{Theoretical Backgroud}

\subsection{Debentures}

Debentures can be defined as securities, according to Law No. 6.385, of July 12,1976 - art. 2nd, l; credit securities, according to Law No. 6.404, of December 15, 1976 - art. 52; or as extra-judicial enforceable titles, as Law No. 13.105, of March,16, 2015 - art. 784, I. 
According to Pinheiro (2016), these securities issued by companies in order to raise medium and longterm funds, are usually intended to either finance projects or to lengthen the debt profile. As shown in Figure 1 below.

Figure 1 -Debentures Issuance Process

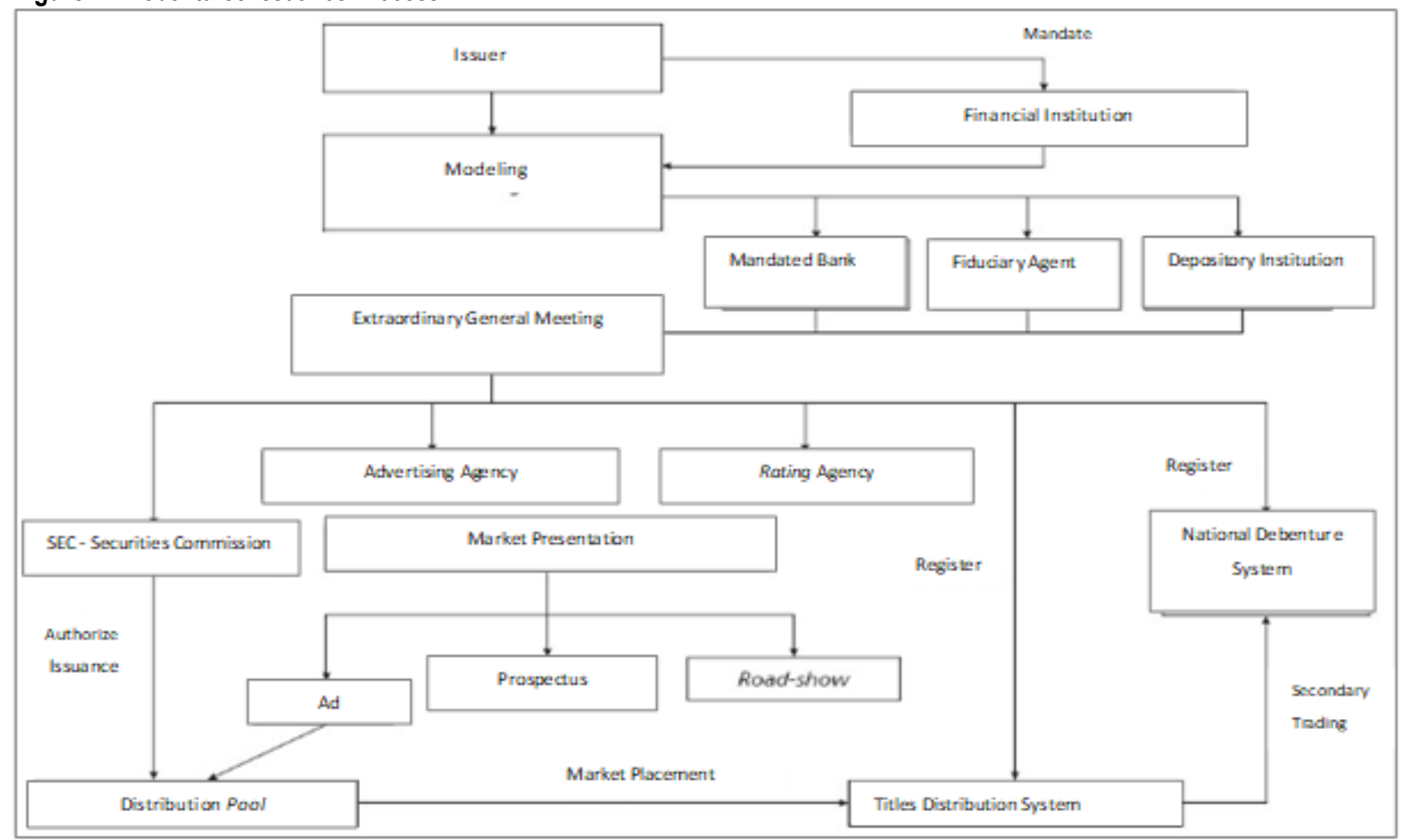

Source: Pinheiro, 2016.

The Comissão de Valores Mobiliários - CVM (2019) highlights that the debenture consists of a fundraising instrument in the capital market, to which companies resort in order to finance their projects and otherwise the CVM highlights that debentures are private credit securities in which debenture holders are creditors of the company and expect to receive periodic interest and payment of the principal.

The B3 (2019) 1 informs that debentures can be remunerated in the following ways:

- A fixed interest rate; or

- A fixed interest rate adjusted, up or down, by one of the following rates: Reference Rate (RR), Long-Term Interest Rate (LTIR), Basic Financing Rate (BFR), or floating rates regularly calculated, being publicly available and based on operations contracted at fixed market rates.

- $\quad$ Alternatively, it is allowed the issuance of debentures with a monetary correction clause based on the coefficients fixed for the monetary correction of federal public securities, exchange rate variation or price index, adjusted, up or down, by fixed rate.

Regarding classification, the debentures are in the following categories:

\footnotetext{
1 The name B3 means Brazil, Bolsa (Stock Exchange), and Balcão (Business Desk). B3 is responsible for the Stock Exchange in Brazil, besides incorporating the Commodities and Futures Exchange, in addition to CETIP (Central for Custody and Financial Settlement of Private Securities), a custody institution of public and private securities. B3 is the company responsible for the Stock Exchange and it is also listed on the Stock Exchange itself. In fact, it is listed as present in the new market, the highest level of corporate governance in Brazil.
} 
- $\quad$ As to the Form: It can be nominative or book-entry;

- $\quad$ As to the Convertibility (Class): Can be convertible or non-convertible (Simple);

- $\quad$ As to the Guarantee or Class: According to the issuance deed, it can be Brazilian Real (R\$), Floating, Unsecured, Subordinated (see also accessory limits and guarantees).

Law 12.431/2011, known as the Infrastructure Debentures Law, brought a package of tax benefits (income tax and FTT - Financial Transaction Tax) to investors, interested in acquiring credit securities for infrastructure projects. The proposal was an option that would bring incentives to investors, so that demand is stimulated, leading to an increase in infrastructure development in the country (Bicalho, 2014). The objective of this new law was to restructure the sector regulation and forms of taxation, that is, to foster the capital market making infrastructure debentures a more attractive mechanism for private capital (Matos, 2014).

With the law implementation, the debentures come to have a particular profile and a tax benefit for certain investors, thus segmenting the market into two major groups: encouraged debentures and nonencouraged or corporate debentures (Almeida \& Bazilio, 2015). The difference between types is that the incentive debentures correspond to variations of conventional debentures, since they have tax benefits, which are different for residents abroad than for domestic residents. The difference lies in the income tax, which is zero for residents abroad, and, in the case of domestic residents, it is $15 \%$ when the debenture is acquired by legal investors, and null when acquired by individual investors (Bragança, Pessoa \& Souza, 2015).

Subsidies for infrastructure are justified on the understanding that projects have social and environmental benefits (externalities). Thus, it aims to reduce the cost of financing infrastructure projects, providing a reduction in the gap between private profitability and social return (Pereira \& Miterhof, 2019).

According to Martits and Fraletti (2014), the encouraged debentures have some limitations that can impact their demand, the main one being the form of compensation of these securities. By law, this type of debenture can only be paid through: fixed interest, inflation index - Broad National Consumer Price Index (IPCA) or indexed by the Reference Rate (TR).

\subsection{The debentures market}

The Capital Markets Bulletin released by ANBIMA - Brazilian Association of Financial and Capital Market Entities - (2019) regarding domestic issues in 2018 shows that fixed income assets increased their share in the total issued (89\% in 2018 against $77 \%$ in 2017). The entity analyzes that this performance was influenced by the growth in the debenture's issuance, which, in 2018, accounted for $65 \%$ of all issuances in the year - in 2017 it was $45 \%$.

For ANBIMA also highlighted the change in the debentures issuance profile in 2018 compared to 2017: there was a reduction in the participation of institutional investors (61\% in 2017 and 51\% in 2018), an increase in the average term from 4.7 to 6,2 years and a significant reduction in the securities whose maturity is up to three years (from $45 \%$ to $29 \%$ ).

The entity credits this profile amendment to the increase in the portion of debentures issued through Law No. 12,431 / 2011, which for being directed to infrastructure projects and for being exempt from income tax for individuals, such debentures have a longer maturity and liquidity in the secondary market. During 2018 it was registered the issuance of $R \$ 23.6$ billion of encouraged debentures against $R \$ 9.1$ billion in 2017 , more than double that of 2016 , when it reached only $\mathrm{R} \$ 4.4$ billion.

Notwithstanding the growth seen in 2018 compared to the previous year, it should be noticed that there remains a small representation of encouraged debentures in relation to the total number of issued debentures: in 2018, $R \$ 140$ billion in debentures were issued. That is, the percentage of encouraged debentures reached $16.9 \%$ of total issues (in 2017 , this percentage was $9 \%$ ). These figures corroborate the study by Almeida and 
Bazilio (2015), where it is noticed that the encouraged debentures, though representing a small percentage of total debentures issues, have a greater distribution in the market, which may cause higher liquidity of securities in the secondary market.

These figures also seem to confirm the analysis by Wajnberg (2014), who carried out a study on the issuance of infrastructure debentures held until the end of 2013. At that time, the author realized it was too early to draw conclusions about the encouraged debentures, and that the low volume captured until December 2013 ( $R \$ 5$ billion) was much more a reflection of its short existence than of failures in the instrument design. The author also believed that the encouraged debentures apparently have greater acceptance, on both the supply and the demand side.

Even with an increase in the issuance of incentive debentures over the years, from the study of Almeida and Bazilio (2015), it is understood that some measures are necessary to accelerate the development of the incentive debentures market, these measures encompass four dimensions: (i) incentive to the offering of debentures; (ii) incentive to demand for debentures; (iii) regulatory framework; and (iv) secondary market structure.

One element that certainly contributes to the popularity of this form of fundraising is the BNDES incentive for such practice. Siffert (2016) states that in all infrastructure projects, BNDES has encouraged the issuance of debentures, which represent $10 \%$ of CAPEX (capital expenditure), and such debentures must be issued during the project's implementation phase.

In another study, Wajnberg (2015) analyzed the effectiveness of infrastructure debentures after 5 years of their existence. The author concluded that the law has generally been achieving its objectives, even in an adverse scenario for corporate security issues of fixed income. For the author, there were signs of an effective development of a niche in the capital market, made up of debentures of infrastructure projects. On the other hand, the author did not fail to consider that improvements in regulation, improvements in related processes and improvements in the performance monitoring of this public policy can and should be pursued.

Another study, prepared by Bragança, Pessoa and Souza (2015), who discussed the recent debentures market evolution in Brazil, whose objective was to study descriptively 1,183 debentures issued between January 2000 and December 2013, pointed out that the national market of debentures has grown in recent years, but it still presents unfavorable features for the long-term investment, such as the low term of assets and the participation focused on financial agents and investment funds.

A similar conclusion comes from the Economic Journal "Valor Econômico", for whom the capital market fails in financing infrastructure. An expert heard by the aforementioned Journal believed that infrastructure investments stood around $\mathrm{R} \$ 100$ billion in 2018 and, of this total, around $\mathrm{R} \$ 9$ billion would come from the capital market" (which has not been confirmed, since the year recorded $\mathrm{R} \$ 23.6$ billion in encouraged debenture issues). The above mentioned Journal believed that market share tended to grow due to the creation of the Long Term Rate (LTR), which will bring BNDES rates closer to market rates. However, this growth should be slow.

In another aspect, Delbem (2016) seeks to determine the tax benefits impact on the pricing of infrastructure debentures. The study covers a total of 2039 series of debentures issued between 2006 and 2015 that were extracted from Anbima's database. The empirical study has not found evidence that the credit spread of an infrastructure debenture was equivalent to a credit spread of any debenture, adjusted by income tax and other risk factors.

Unlike the approach taken by Delbem (2016), which identified a number of variables that contribute to the debentures pricing, this study aims at assessing different spreads only for the issues of companies that have issued debentures with and without the tax benefit.

At this point, to the same extent that the limitation of this study is pointed out, namely, the failure to examine other factors that determine the formation of the interest rate of these securities (economic moment, rating, issue size, etc ...), the succinct approach proposed by the present analysis highlights the explanatory 
power of the issuing company as a decisive factor to capture the risk perceived by investors. That is, it is assumed that, when considering the same issuing company, the perceived risk would be similar.

\subsection{Determinants of Corporate Bond Sprad}

According to the Finance Theory, the spread is a difference between the interest rate on public securities and the interest rate on private securities. This kind of measurement is based on the concept that the risk-free interest rate occurs when the country is the issuer of its currency. Therefore, this difference is the security spread, which can also be understood as the credit risk of these companies.

However, credit risk is not the only crucial variable in the formation of corporate securities spread. There are other variables such as: security term, liquidity, governance, guarantees, interest rates and country risk. These variables influence the formation of security spreads both abroad and in Brazil (Caires, 2019).

In Brazil, some studies are classical regarding debentures, as Mellone, Eid Júnior and Rochman (2002) apply a regression analysis comparing the influences of variables such as rating, term, guarantee, type, and class. Another worth mentioning is the article by Sheng and Saito (2005), where they analyzed the impact of credit rating in determining the debentures spread.

The study by Fraletti and Eid Júnior (2005), on the other hand, seeks to understand the relation between the rating and the revenue of debentures through least squares. The work presented by Paiva (2006) also addresses the variables that influence the debentures spread, but its innovation comes with the inclusion of macroeconomic variables in the model. Following the innovation line, Gonçalves and Sheng (2010) study the spread using some proxies in view of the liquidity risk that is inherent to the trading data of the secondary debentures market.

In view of the Interbank Deposits - the Dl's law coming into force, new studies and approaches are presented, according to Delben (2016), who assessed the impact of the tax benefit granted to investors for investments in infrastructure or encouraged debentures. This study, using a statistical regression model, has the purpose of verifying which factors can influence the credit spread of the debentures. The result shows that the tax benefit limits the market for infrastructure debentures, since the non-inclusion of investment funds in the benefit range causes a distortion, resulting in a spread smaller than the risk premium demanded by investors. This finding corroborates a case study on the company Ecovias dos Imigrantes in the issuance of its infrastructure debenture, carried out by Martits and Fraletti (2014), where the infrastructure debentures limitation is placed precisely in the impossibility of investment funds not being able to enjoy the tax benefit.

In relation to the spread and debentures, the second article of Law 12.431 creates infrastructure debentures, and differentiates corporate and individual investors in terms of taxation. Table 1 presents a comparison between the tax regime between the incentive debentures and the conventional debentures:

Table 1: Tax Comparison in relation to Debentures

\begin{tabular}{c|c|c|c}
\hline \hline \multirow{2}{*}{ Investment } & Investor & Income Tax & $\begin{array}{c}\text { Financial Transaction } \\
\text { Tax }\end{array}$ \\
\hline \hline \multirow{3}{*}{ Incentive Debentures } & Individual & $0 \%$ & - \\
\cline { 2 - 4 } & Corporate & $15 \%$ & $0 \%$ \\
\cline { 2 - 4 } & No-Residents & $0 \%$ & - \\
\hline
\end{tabular}




\begin{tabular}{l|c|c|c}
\cline { 2 - 3 } Conventional Debentures & Corporate & $25 \%$ & - \\
\cline { 2 - 4 } & No-Residents & $15 \%$ & $6 \%$ \\
\hline
\end{tabular}

Source: Prepared by the authors, 2020.

The information in Table 1 shows that the law sought to solve the problems of both sides, both in terms of supply and demand. In the view of Delben (2016), by offering a reduction in the income tax rate, it encourages investors, given that their profits will be greater than other investments that present the same return. Following the author's opinion, the demand for this type of security is stimulated, making private investors more involved in the development of infrastructure in the country.

Therefore, the tax incentive that the encouraged debentures receive is a determining factor in measuring the spread of this category of debentures. Since this characteristic of this corporate bond makes the spread of the incentive debentures smaller than the risk premium required by this type of investor.

\section{Methodological Procedures}

In this work, it was analyzed how the new law that brought tax incentives impacted the spread of incentive and non-incentivized debentures in the Brazilian market. Thus, the study is characterized, in terms of ends, as descriptive. As for the means, this is an exploratory research, considering that data from negotiations observed in the Brazilian debenture market were used, in order to understand initially the relationship between the spread of the bonds and the implementation of the new law. Regarding the approach to the problem, the study is characterized primarily as quantitative, given the use of data and statistical percentages in the analyzes focused on measuring the phenomenon from the collected numbers.

Data and statistics on debentures issues that occurred in Brazil from 2012 through 2018 were collected. The source was the database of the National Debentures Module, which provides all data and documents related to issues registered in the SDN (National Debentures System), this database is managed by ANBIMA.

The period had 1233 debentures issuances. In total, there were 224 issues of encouraged debentures by 147 different companies. Of this total, 46 companies issued, in addition to encouraged debentures, nonencouraged debentures, in order to enable the analysis between these two types of issuance. Two companies were not considered in the sample, which issued pre-fixed debentures and indexed by the IGP-M. Thus, the sample consists of 44 companies and 178 issuances.

The spread was defined as the difference between the interest rate offered by any debenture selected in the sample and the interest rate offered by the most similar government bonds available. For calculation purposes the debentures were grouped into two groups:

- $\quad$ Debentures indexed by the IPCA - These debentures have an average maturity of 6.8 years and their rates will be compared with the purchase rates of the Tesouro IPCA +2 title on the same date of issuance of the debentures (or, if unavailable, of the immediately preceding date) with a similar term on the same issuance date.

- Debentures indexed by the DI (Interbank Deposits) - These securities have an average maturity of 4.7 years and their rates will be compared with the purchase rates (early morning) of the Tesouro

\footnotetext{
2 Tesouro IPCA+ - Treasury Broad National Consumer Price Index (Tesouro IPCA+) are securities with profitability linked to the variation of the IPCA, plus interest defined at the time of purchase. As it is a post-fixed security, returns to be received by the investor will vary until the maturity date.
} 
SELIC ${ }^{3}$ security on the same issuance date of the debentures (or, if unavailable, the immediately preceding date) with a similar maturity on the same date of issuance.

The samples will be analyzed as to their descriptive statistics, and a mean difference test will be performed using the $t$-statistic at $5 \%$ significance. In addition to the t-statistic test, the non-parametric Kolmogorov-Smirnov test was applied. Where $\mathrm{H}_{0}$ : The data follows a normal distribution; $\mathrm{H}_{1}$ : The data does not follow a normal distribution.

If the $t$ statistic points to the rejection area of the null hypothesis, that is, if a "p" value less than 0.05 is found, the null hypothesis is rejected and, consequently, it is not rejected the alternative hypothesis that the average spread of encouraged debentures is not smaller than the average spread of non-encouraged debentures.

\section{Results Analysis}

The descriptive statistical analysis of the spread of the debenture samples reveals that only the debentures indexed by the DI series showed a significant approximation with the normal distribution (the Komogorov-Smirnov statistics did not reject the null hypothesis of distribution normal at the $5 \%$ level). The descriptive spreads statistics are summarized in Table 2.

Table 2: Spreads Analysis

\begin{tabular}{c|c|c|c}
\hline Statistics & $\begin{array}{c}\text { Non-encouraged } \\
\text { debentures (A) }\end{array}$ & $\begin{array}{c}\text { Encouraged debentures } \\
\text { (B) }\end{array}$ & Differences (A-B) \\
\hline Average Spread & $0,73 \%$ & $0,52 \%$ & $0,21 \%$ \\
\hline Median spread & $0,46 \%$ & $0,42 \%$ & $0,04 \%$ \\
\hline Standard deviation of spread & $0,78 \%$ & $0,79 \%$ & $-0,01 \%$ \\
\hline Spread variance & $0,01 \%$ & $0,01 \%$ & $0,00 \%$ \\
\hline Minimum & $-0,02 \%$ & $-0,79 \%$ & $0,77 \%$ \\
\hline Maximum & $2,49 \%$ & $2,47 \%$ & $0,02 \%$ \\
\hline Volume raised (R\$ million) & 44.741 & 18.917 & 25.824 \\
\hline
\end{tabular}

Source: Prepared by the authors, 2019.

For 26 companies, or $60 \%$ of the cases, the spread of the encouraged debentures compared to the government bonds was smaller than that of the non-encouraged debentures.

The statistical $t$-test, comparing the average spread of encouraged debentures and non-encouraged debentures, is 0.1094 . This indicates that, for commonly used significance levels (up to $5 \%$ ), one cannot rule out the null hypothesis that the average spreads between the two groups are equal.

As for the representativeness of funding through encouraged debentures, it was found that around $30 \%$ of funding made by the analyzed companies was raised through encouraged debentures.

This point is relevant and helps to reflect on the research problem since it indicates that encouraged debentures were not the main way of funding among companies that issued encouraged and non-encouraged debentures. In other words, in addition to the fact that the encouraged debentures do not have a spread that is significantly smaller than the non-encouraged debentures, they also did not represent the main alternative used by companies.

\footnotetext{
3 Tesouro SELIC - Treasury Special Settlement and Custody System (Tesouro SELIC) are post-fixed securities that have a return linked to the Selic Rate. The Selic Rate is the basic interest rate of the Brazilian economy.
} 
On the other hand, this point, regarding the representativeness of funding through encouraged debentures, may also be a possible consequence of the fact that the encouraged debentures do not have significantly smaller spreads, in addition to requiring additional procedures with the sector ministry. In other words, it would be to say: given that the encouraged debentures do not have significantly lower spreads, companies do not primarily resort to this kind of issuance, due to the additional bureaucracy for approval by the Government.

Graph 1 illustrates the share of each activity sector in encouraged debentures fundraising:

Graph 1: Allocation of Funds Raised

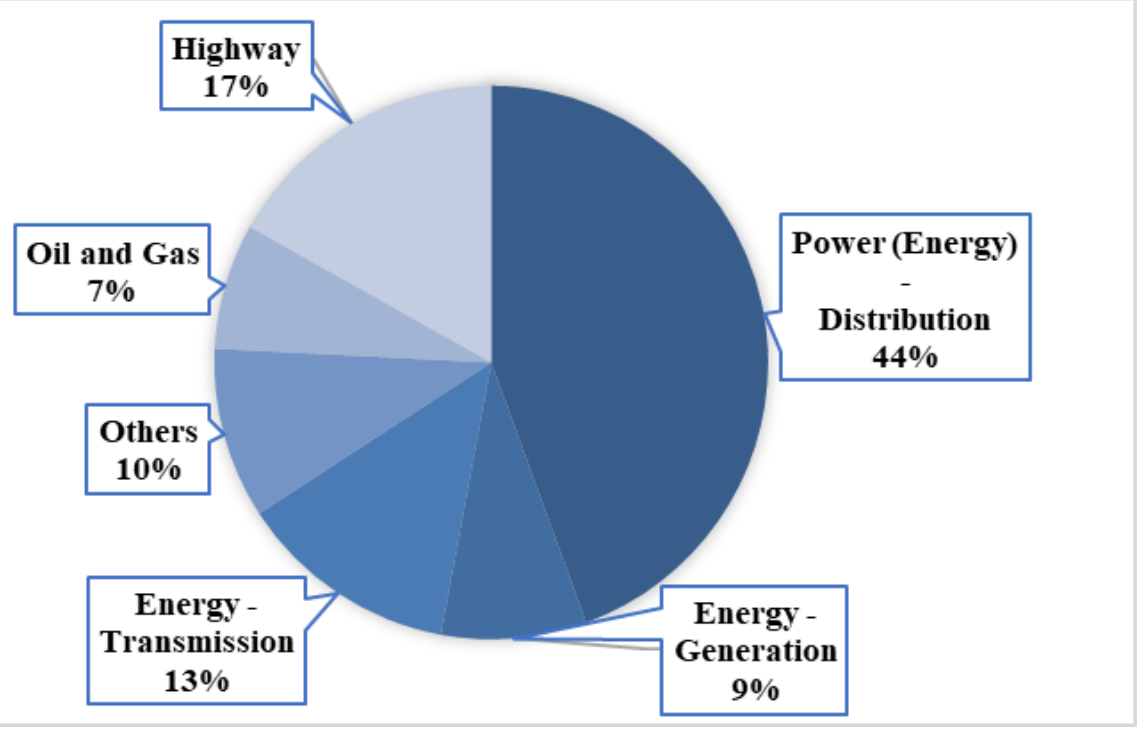

Source: Prepared by the authors, 2019.

The chart above shows great preponderance of the electric power sector in raising funds through encouraged debentures. The distribution sector alone accounts for $44 \%$ of the funds raised.

Also noteworthy is the participation of the oil and gas sector represented by a single company, Petrobras $\mathrm{S} / \mathrm{A}$, which accounted for $9 \%$ of all funding. There is also the need to comment on the absence of certain infrastructure sectors such as airport and port.

Another complementary analysis concerns the investigation of the possible greater use of encouraged debentures during the economic crisis period recently faced by Brazil.

As reported by Reuters Brasil (2017), evaluating data from the Brazilian Institute of Geography and Statistics - IBGE, in the first quarter of 2017, Brazil's Gross Domestic Product (GDP) grew 1 percent in relation to the previous three months and, therefore, ended two consecutive years of recession. Thus, it is relevant to investigate whether, during the economic crisis period (years of 2015 and 2016, mainly), the encouraged debentures played a greater role for financing infrastructure projects.

Graph 2 lists the quarterly volume of funds raised through infrastructure debentures with the GDP recorded in the respective quarter compared to the same quarter of the immediately previous year. 
Graph 2: Volume raised x quarterly GDP

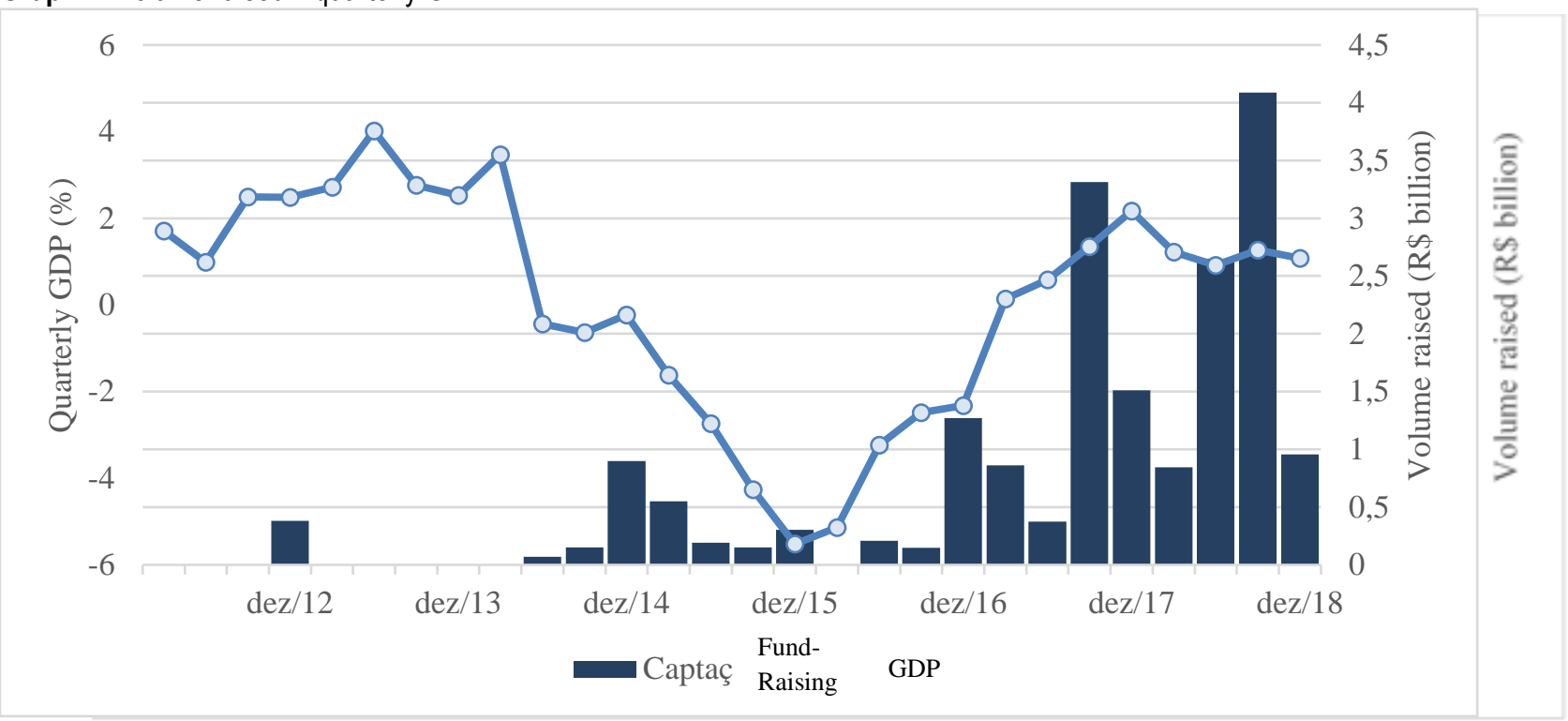

Source: Prepared by the authors, 2019.

The data reveal no major role of encouraged debentures during the crisis. Quite the contrary, the amount raised through these instruments appears to have a positive correlation to the country's GDP, in that, at times when GDP was positive and high, funding was also higher, and the opposite was also noticed. This indicates that the encouraged debentures were not an alternative financing instrument during the economic crisis.

\section{Conclusion}

This study sought to analyze the influence of Law No. 12,431 / 2011 on the distribution of debentures, through an analysis of differences between the spreads of the types of debentures. Thus, the objective of the article was to investigate whether the incentive debentures provided cheaper financing for investment projects.

As a conclusion, it was observed that it was not possible to accept the hypothesis that the incentive debentures have a lower average spread. Thus, the Dl's law did not prove to be an efficient mechanism, causing, according to Pereira and Miterhof (2019), a fiscal inefficiency in the granted subsidies distribution, generating distortion in the debentures market. In accordance with the understanding of Wajnberg and Castro (2016), Law 12,431 , unfortunately does not contribute to liquidity in the secondary market since it is seen as less important for buy-and-hold investors.

Likewise, it was also possible to observe that, among the companies that raised encouraged and nonencouraged debentures, fundraising through non-encouraged debentures was predominant, accounting for about $70 \%$ of the origin of this type of resource. According to Pereira and Miterhof (2019), the division into special taxation regimes, in the case of infrastructure debentures, impacts the capital market by making the measurement of tax benefits opaque, distorting the economic signs of asset prices and segmenting an already small market in several pockets of even less profound liquidity. This result corroborates the evidence found by Pimentel, Peres and Lima (2011), who portray that the Brazilian debentures market is still incipient when compared to other developed countries.

Unfortunately, the encouraged debentures proposal did not have the result expected by the Government. Even though it is not the objective of this study, we can present some explanations and reasons that justify the proposal for the infrastructure debentures to have failed. According to some authors such as Bicalho (2014), Passos and Mendes-da-Silva (2014), Almeida and Bazilio (2015), Wajnberg and Castro (2016) 
some situations contributed to the non-achievement of the proposed goals, among them: macroeconomic uncertainties, high interest rates as from 2013 and concentration of projects funding by BNDES. Other factors also influence the encouraged debentures market performance, including: i) non-uniform procedures for issuance approval, ii) low fundraising appeal for infrastructure projects and iii) low liquidity in the secondary market (Pimentel, Borinelli, Lima \& de Lima, 2008; Passos \& Mendes-da-Silva, 2014, Wajnberg \& Castro, 2016).

Furthermore, it was found that, during the economic crisis recently faced by Brazil, companies have not sought, with greater momentum, financing through encouraged debentures. On the contrary, it was found that, apparently, the amount raised through encouraged debentures may have a positive correlation with the Gross Domestic Product.

As for the sectors that most resorted to this fundraising type, there was a great preponderance of the electric energy sector in fundraising through encouraged debentures, this result is evidenced in the work of Passos and Mendes-da-Silva (2014). It was shown the distribution sector relevance, which alone accounts for $44 \%$ of the funds raised via this type.

It is noticed the limitation of the analysis carried out, insofar as it was investigated exclusively the presence of spread difference between encouraged debentures and other debentures. Other determinants of spread were not part of the analysis scope.

The research contribution involves questioning the federal government's public incentive policies. Several questions may arise regarding this finding, among them:

- $\quad$ Did the influence of factors not considered in the analysis prevent findings regarding the relevance of the tax incentive for infrastructure debentures?

- $\quad$ Could it be that, in fact, government policy has not had the expected effects of lowering the cost of funding for investments in infrastructure?

\section{- What are the other possible alternatives to lower the cost of funding for investments in infrastructure?}

Another contribution is related to the debentures market in Brazil, the research provided a new analysis on this investment market in recent years.

The questions raised above are possibilities for studies that can be investigated in future research. In addition to a complementary approach according to the studies by Golçalves and Sheng (2010), Giacomoni and Sheng (2013), Almeida and Bazilio (2015), in which they deal with the debenture's liquidity risk and its determinant factors in the secondary market.

\section{Referências}

Almeida, C. A. D., \& Bazilio, J. K. (2015). Liquidez do mercado secundário de debêntures: dinâmica recente, fatores determinantes e iniciativas. Revista do BNDES, 44, 175-223.

Assaf Neto, A. (2014). Finanças Corporativas e Valor. (7a ed.). São Paulo: Atlas.

Associação Brasileira das Entidades dos Mercados Financeiro e de Capitais - ANBIMA. (2008). Estudos Especiais - Captação de Produtos. Certificados de Recebíveis Imobiliários. Rio de Janeiro. Disponível em: https://www.anbima.com.br/data/files/BB/C0/CB/48/2EB675106582A275862C16A8/GuiaCRI-05-Nov_1_.pdf

Associação Brasileira das Entidades dos Mercados Financeiro e de Capitais - ANBIMA. (2019). Boletim de Mercado de Capitais. Relatórios, São Paulo. Disponível em: https://www.anbima.com.br/pt br/informar/relatorios/mercado-de-capitais/boletim-demercado-de-capitais/ativos-de-renda-fixa-corresponderam-a-89-das-captacoes-domesticas.htm

Associação Nacional das Instituições do Mercado Financeiro - ANBIMA (2019). Projetos e Emissões Incentivadas (Lei 12.431). Estatísticas, Mercado de Capitais. São Paulo. Disponível em: https://www.anbima.com.br/pt_br/informar/estatisticas/mercado-decapitais/projetos-e-emissoes-incentivadas-lei-12-431-consolidado-historico.htm 
Braga, K. (2016). As debêntures incentivadas na conjuntura do financiamento de longo prazo de infraestrutura no Brasil. Prêmio ABDE-BID, Coletânea de Trabalhos. Rio de Janeiro. Disponível em: http://abde.org.br/wp-content/uploads/2018/06/PREMIOABDE-2016 Completo Menor.pdf\#page=79

Bragança, G. G. F., Pessoa, M. S., \& Souza, G. M. (2015). Evolução do Mercado de Debêntures no Brasil: as Debêntures Incentivadas. Instituto de Pesquisa Econômica Aplicada - IPEA. Texto para Discussão - 2158. Rio de Janeiro.

Brasil. (1976a). Lei $n^{\circ}$. 6.385, de 07 de dezembro de 1976. Dispõe sobre o mercado de valores mobiliários e cria a Comissão de Valores Mobiliários. Recuperado de: http://www.planalto.gov.br/ccivil_03/LEIS/L6385.htm

Brasil. (1976b). Lei $n^{0}$. 6.404, de 15 de dezembro de 1976. Dispõe sobre as Sociedades por Ações. Recuperado de: http://www.planalto.gov.br/ccivil_03/leis//6404consol.htm

Brasil. (2011). Lei $n^{0}$. 12.431, de 24 de junho de 2011. Dispõe sobre a incidência do imposto sobre a renda nas operações que especifica; altera as Leis $n^{\circ} \mathrm{s} 11.478$, de 29 de maio de 2007, 6.404, de 15 de dezembro de 1976, 9.430, de 27 de dezembro de 1996, 12.350, de 20 de dezembro de 2010, 11.196, de 21 de novembro de 2005, 8.248, de 23 de outubro de 1991, 9.648, de 27 de maio de 1998, 11.943, de 28 de maio de 2009, 9.808, de 20 de julho de 1999, 10.260, de 12 de julho de 2001, 11.096, de 13 de janeiro de 2005, 11.180, de 23 de setembro de 2005, 11.128, de 28 de junho de 2005, 11.909, de 4 de março de 2009, 11.371, de 28 de novembro de 2006, 12.249, de 11 de junho de 2010, 10.150, de 21 de dezembro de 2000, 10.312, de 27 de novembro de 2001, e 12.058, de 13 de outubro de 2009, e o Decreto-Lei n 288, de 28 de fevereiro de 1967; institui o Regime Especial de Incentivos para o Desenvolvimento de Usinas Nucleares (Renuclear); dispõe sobre medidas tributárias relacionadas ao Plano Nacional de Banda Larga; altera a legislação relativa à isenção do Adicional ao Frete para Renovação da Marinha Mercante (AFRMM); dispõe sobre a extinção do Fundo Nacional de Desenvolvimento; e dá outras providências. Recuperado de: http://www.planalto.gov.br/ccivil_03/_Ato2011-2014/2011/Lei/L12431.htm

Brasil. (2015). Lei $n^{0}$. 13.105, de 16 de março de 2015. Código de Processo Civil. Recuperado de: http://www.planalto.gov.br/ccivil_03/_ato2015-2018/2015/lei/l13105.htm

B3 - Brasil Bolsa Balcão. (2019). Debêntures. Títulos Privados. São Paulo. Disponível em: http://www.b3.com.br/pt_br/produtos-eservicos/negociacao/renda-fixa/debentures.htm

Bicalho, F. C. (2014). Debêntures de Infraestrutura: perspectivas da Lei 12.431/11. 42 f. Trabalho de Graduação, Universidade de Brasilia, Brasília. Disponível em: http://bdm.unb.br/handle/10483/7989

Caires, M. T. D. (2019). Determinantes dos spreads de emissão das debêntures no mercado brasileiro: o impacto das garantias. 59 f. Dissertação de Mestrado, Fundação Getúlio Vargas, São Paulo. Disponível em: https://bibliotecadigital.fgv.br/dspace/handle/10438/27886

Cavalho, L. N. D. (2017). Captação de recursos de longo prazo: as opções disponíveis às empresas brasileiras com foco no mercado de debêntures. 43 f. Trabalho de Graduação, Universidade federal do Rio de Janeiro, Rio de Janeiro. Disponível em: https://pantheon.ufri.br/handle/11422/4869

Çelik, S., Demirtaş, G., \& Isaksson, M. (2015). Corporate bonds, bondholders and corporate governance. OECD: Corporate Governance, Working Paper n. 16. Available in: https://www.oecd-ilibrary.org/docserver/5js69lj4hvnwen.pdf?expires=1578767190\&id=id\&accname=guest\&checksum=BF1D24DBBCB2699B29C57B5C76EF1AF0

Comissão de Valores Mobiliários - CVM. (2019). Debêntures. Portal do Investidor. Rio de Janeiro. Disponível em: https://www.investidor.gov.br/menu/Menu_Investidor/valores_mobiliarios/debenture.html

Decreto-Lei $n^{\circ}$. 157, de 10 de fevereiro de 1967. Concede estímulos fiscais à capitalização das empresas; reforça os incentivos à compra de ações; facilita o pagamento de débitos fiscais. Recuperado de: http://www.planalto.gov.br/ccivil_03/Decreto-Lei/19651988/Del0157.htm

Delbem, F. C. (2016). Impacto do benefício fiscal no apreçamento das debêntures de infraestrutura. 56 f. Dissertação de Mestrado, Fundação Getúlio Vargas, São Paulo. Disponível em: https://bibliotecadigital.fgv.br/dspace/handle/10438/17388

de Oliveira, P. G. (2019). Os Entraves Institucionais para uma maior Participação do Setor Privado no Financiamento da Infraestrutura: O Caso das Debêntures Incentivadas. 116 f. Dissertação de Mestrado, (Master's Thesis) Instituto de Pesquisa Econômica Aplicada, Brasília. Disponível em: http://www.ipea.gov.br/sites/images/mestrado/turma3/patricia-goncalves-de-oliveira.pdf

de Vasconcelos, V. H. S., de Sousa, F. W. S., Araújo, J. C. O., \& de Souza, P. V. S. (2018). Fatores Determinantes do Spread de Debentures das Empresas de Infraestrutura Listadas e não Listadas na BMF\&Bovespa. Congresso Nacional de Administração e Contabilidade - AdCont, IX, Anais. Rio de Janeiro. Disponível em: http://adcont.net/index.php/adcont/adcont2018/paper/view/3138

Di Pietro, M. S. Z. (2017). Parcerias na Administração Pública: concessão, permissão, franquia, terceirização, parceria público-privada e outras formas. $11^{\mathrm{a}}$ ed. São Paulo: Editora Forense. 
Fraletti, P. B., \& Eid Júnior, W. (2005). A relevância do rating e de outros fatores na determinação do rendimento das debêntures emitidas no mercado brasileiro. Fundação Getúlio Vargas, Working Paper, São Paulo.

Giacomoni, B. H., \& Sheng, H. H. (2013). O impacto da liquidez nos retornos esperados das debêntures brasileiras. Revista de Administração-RAUSP, 48(1), 80-97.

Gonçalves, P. E., \& Sheng, H. H. (2010). O apreçamento do spread de liquidez no mercado secundário de debêntures. Revista de Administração-RAUSP, 45(1), 30-42.

Houweling, P., Mentink, A., \& Vorst, T. (2005). Comparing possible proxies of corporate bond liquidity. Journal of Banking \& Finance, 29(6), 1331-1358.

Martits, L. A., \& Fraletti, P. B. (2014). Reestruturação financeira e emissão de debêntures: o caso Ecovias dos Imigrantes. Revista Brasileira de Casos de Ensino em Administração, 4(2), c14.

Matos, R. F. P. (2014). O mercado de debêntures brasileiro e as novas "debêntures incentivadas". 33 f. Trabalho de Graduação, Universidade Federal do Rio de Janeiro, Rio de Janeiro. Disponível em: https://pantheon.ufri.br/handle/11422/503

Mellone, G., Eid Junior, W., \& Rochman, R. (2002). Determinação das taxas de juros das debêntures no mercado brasileiro. Encontro Brasileiro de Finanças, II, Anais. São Paulo. Disponível em: http://bibliotecadigital.fgv.br/ocs/index.php/ebf/2EBF/paper/view/1659

Menezes, D. F. N., \& de Andrade, R. P. (2018). Panorama Histórico da Edição da Lei nº 6.404 de 1976 e Debêntures de Infraestrutura. Revista Jurídica Luso-Brasileira, 4 (2), 827-845.

Moll, J. (2018). Rational Choice Theory. In: Hoque, Z. (Org.). Methodological Issues in Accounting Research: Theories and Methods. $2^{\mathrm{a}}$ ed. London: Spiramus Press Ltd.

Nunes, R. M. (2014). Títulos de dívida corporativa de empresas brasileiras: investir em emissões do mercado interno ou externo? 52 f. Dissertação de Mestrado, Fundação Getúlio Vargas, São Paulo. Disponível em: https://bibliotecadigital.fgv.br/dspace/handle/10438/11484

Oliveira, R. C. R. (2015). Administração pública, concessões e terceiro setor. $3^{a}$ ed. rev., ampl. e atual. São Paulo: Editora Método.

Passos, G. D., \& Mendes-da-Silva, W. (2014). Legislação Específica Para Infraestrutura e P\&D Induz Redução do Risco de Debêntures no Brasil. Revista de Finanças Aplicadas, 2, 1-35.

Paiva, E. V. D. S. (2006). Fatores determinantes do preço de emissão primária de debêntures no Brasil: uma análise exploratória. 167 f. Dissertação de Mestrado, Universidade de São Paulo, São Paulo. Disponível em: https://teses.usp.br/teses/disponiveis/12/12139/tde-09112006-101926/en.php

Pereira, T. R., \& Miterhof, M. T. (2019). Debêntures de infraestrutura: qual fração do custo fiscal é transferida aos projetos?. Banco Nacional de Desenvolvimento Econômico e Social - BNDES. Textos para Discussão - 143. Disponível em: https://web.bndes.gov.br/bib/jspui/bitstream/1408/18601/3/TD_143_WEB_REV.pdf

Pimentel, R. C., Borinelli, M. L., Lima, I. S., \& de Lima, G. A. S. (2008). Financiamento empresarial brasileiro no mercado de dívida de longo prazo. Enfoque: Reflexão Contábil, 27(1), 23-36.

Pimentel, R. C., Peres, E. F., \& de Lima, G. A. S. F. (2011). O mercado de Debêntures e o Financiamento Produtivo no Brasil: uma Análise de Cointegração e Causalidade. Revista de Contabilidade e Organizações, 5(11), 4-22.

Pinheiro, J. L. (2016). Mercado de Capitais. $8^{a}$ ed. São Paulo: Atlas.

Reuters Brasil (2017). Autores: Patrícia Duarte e Rodrigo Viga Gaier. Economia cresce 1\% no $1^{\circ}$ trimestre e Brasil sai da recessão, mas investimentos ainda sofrem. Notícias Principais. Disponível em: https://br.reuters.com/article/topNews/idBRKBN18S54KOBRTP.

Santi, V. G. (2018). A relevância do rating e de outros fatores na determinação do rendimento das debêntures incentivadas no mercado brasileiro. 24 f. Trabalho de Graduação, Insper, São Paulo. Disponível em: http://dspace.insper.edu.br/xmlui/handle/11224/1905

Sheng, H. H., \& Saito, R. (2005). Determinantes de spread das debêntures no mercado brasileiro. Revista de Administração - RAUSP, 40(2), 193-205.

Siffert, N. (2016). Apoio do BNDES à infraestrutura. In: Um debate sobre Financiamento de Longo Prazo para Infraestrutura - Gargalos e Perspectivas. Câmara Brasileira da Indústria da Construção - CBIC, Brasília. Disponível em: https://cbic.org.br/wpcontent/uploads/2017/11/Um_debate_sobre_Financiamento_de_Longo_Prazo_para_Infraestrutura_2016.pdf

Sistema Nacional de Debêntures - SND. (2019). Módulo Nacional de Debêntures. Disponível em: www.debentures.com.br

Wajnberg, D. (2014). Debêntures de infraestrutura: emissões realizadas e perspectivas. Revista do BNDES, 41, 331-377. 
Wajnberg, D. (2015). Cinco anos de debêntures de infraestrutura: uma avaliação de efetividade do instrumento. Revista do BNDES, 44, 123-173.

Wajnberg, D., \& Castro, E. C. (2016). Debêntures de projetos de infraestrutura: uma comparação entre as experiências brasileira e internacional. Revista do BNDES, 46, 149-155.

\section{DADOS DOS AUTORES}

\section{Rodolfo Vieira Nunes}

Doutorando em Administração de Empresas pela USP

Professor Substituto na UEMA

Endereço: Av. Professor Luciano Gualberto - Butantã.

CEP: 05508-010 - São Paulo/SP - Brasil.

E-mail: rodolfonunes@usp.br

Telefone: (11) 3091-5805

\section{Agostinho Moura dos Santos}

Mestrando em Ciências Contábeis pela UnB

Email: agostinhoms@gmail.com

\section{George André Willrich Sales}

Doutor em Administração de Empresas pela Universidade Presbiteriana Mackenzie

Professor na Faculdade FIPECAFI e na UNIFESP

Endereço: Rua Maestro Cardim, 1170 - Liberdade.

CEP: 01323-001 - São Paulo/SP- Brasil.

Telefone: (11) 3284-2070

\section{Contribuição dos Autores:}

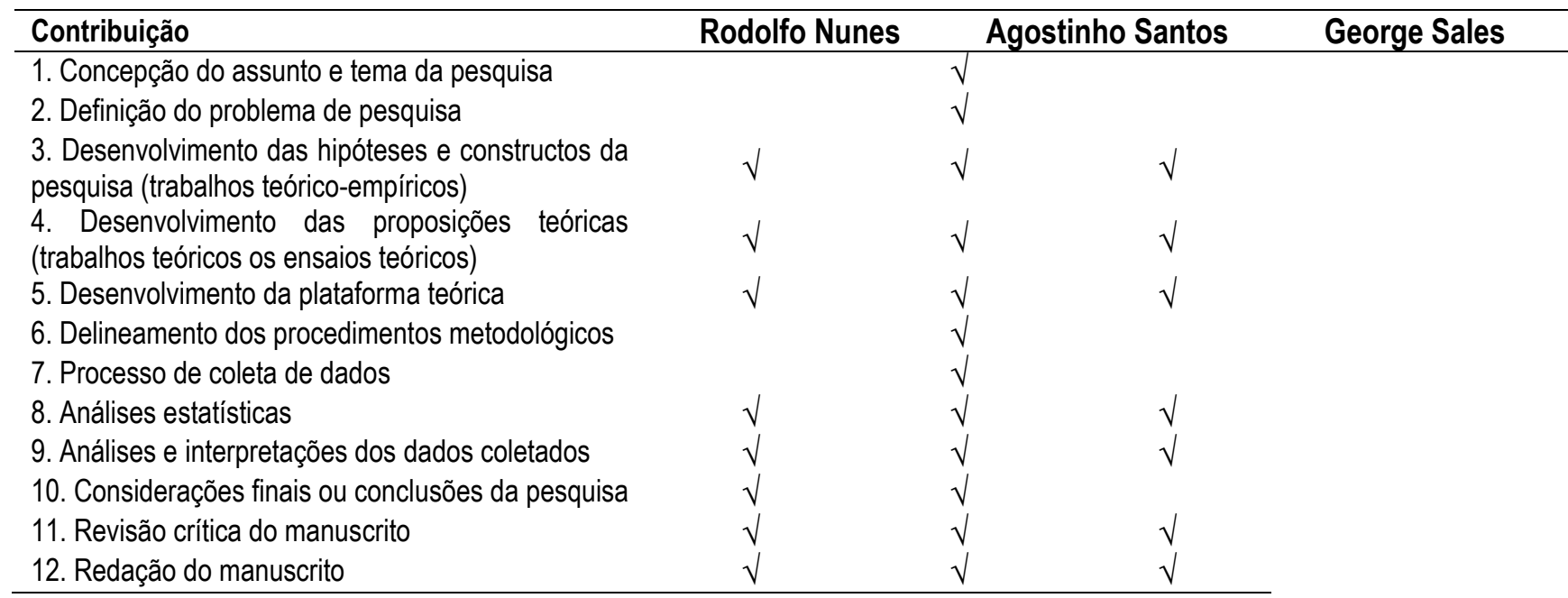

